\title{
O que a telenovela ensina sobre ser mulher? Reflexões acerca das representações femininas
}

\section{What soap opera teaches about being woman? Reflections about female representations}

Lírian Sifuentes

Doutoranda no Programa de Pós-Graduação em Comunicação da PUCRS/RS/BR. lisifuentes@yahoo.com.br

Veneza Ronsini

Professora no Programa de Pós-Graduação em Comunicação Midiática da UFSM/RS/BR. venezar@gmail.com

\begin{abstract}
RESUMO
Neste texto, buscamos refletir sobre o modo como a audiência da telenovela constitui a identidade feminina de jovens mulheres de classe popular. A amostra desta pesquisa, que se configura como uma etnografia da audiência, foi composta por 12 jovens entre 16 e 24 anos, moradoras da periferia de Santa Maria-RS. Os resultados da pesquisa apontam que a carência econômica interfere nas vivências e nos modos de ser mulher, seja pela gravidez na adolescência, pelo trabalho, pelo abandono da escola ou pela televisão como principal forma de lazer. A telenovela também é essencial, pois, se, por um lado, (re) produz um modelo feminino tradicional - em que a maternidade e o casamento são as prioridades femininas -, por outro, faz chegar às entrevistadas indícios de uma representação de igualdade de gêneros, a qual elas não experenciam em seu cotidiano.
\end{abstract}

PALAVras-chave: recepção de telenovela; mediações; relações de gênero

\section{ABSTRACT}

In this paper, we reflect on how the soap opera audience, family and social class constitute the female identity of young working class women. The sample, which is configured as audience ethnography, was composed of 12 young people between the ages of 16 and 24 living on the outskirts of Santa Maria-RS. The results indicate that the economic deprivation interferes in the experiences and ways of being a woman, by teenage pregnancy, by work, by dropping out of school or on television as the primary form of recreation. The soap opera is also essential, because if, on the one hand, (re) produces a traditional female model - in which motherhood and marriage are female priorities - the other, gives evidences of gender equality representations, which they don't experience in their daily lives.

KEYworDs: telenovela reception; mediation; gender relations 
$\mathrm{O}$

interesse em estudar as relações entre as apropriações da mídia e as relações de gênero nasce da comprovada insuficiência de pesquisas que abordem o gênero como categoria teórica e explicativa para o estudo da mídia no âmbito dos Estudos Culturais latino-americanos (Escosteguy, 1998, 2002, 2008; Jacks; Menezes; Piedras, 2008; Meirelles, 2009). Enquanto a trajetória dos Estudos Culturais feministas anglo-americanos inicia na década de 1970, consolidando-se na década de 1980 e permanecendo como um campo notável de estudos, na América Latina, a pesquisa que relaciona gênero e audiência ainda não pode ser considerada consolidada.

O olhar feminista da cultura contribuiu para a valorização do estudo de programas de entretenimento, visto que, até então, apenas programas noticiosos e políticos eram considerados dignos de pesquisa. Destaca-se, a partir daí, a importância do estudo da cultura do ponto de vista do espaço familiar e do cotidiano. Nesse contexto, o interesse pelo estudo dos programas melodramáticos se deu por diversos motivos: tinham como público-alvo as mulheres; faziam interagir as esferas pública e privada, destacando-se o lema feminista "o pessoal é político"; retratavam e eram consumidos no contexto cotidiano; e eram desprestigiados, assim como quem os consumia.

\section{Pensando as relações de gênero e classe social na comunicação}

Com essa perspectiva, ganha valor acadêmico o estudo da soap opera/telenovela, programa de relevância ímpar no Brasil. Contudo, em nosso país, a investigação sobre tal relação se desenvolve tardiamente, o que tem relação com o desprestígio do programa e do próprio público consumidor, as mulheres. Embora os trabalhos sobre telenovela tenham um tímido início na década de 1970, sua consolidação só ocorre na década de 1990. Ademais, até hoje são relativamente escassos as pesquisas que exploram questões de gênero na pesquisa da telenovela.

E importante ressaltar que, se o número de trabalhos que abordam gênero e comunicação é reduzido, a pesquisa brasileira sobre a recepção feminina da mídia é ainda menos significativa. Pouco se busca compreender a leitura feminina da mídia e o papel das apropriações dos meios de comunicação na constituição das identidades das mulheres brasileiras. $\mathrm{O}$ que se verifica com frequência é que a mulher aparece em estudos de recepção apenas como uma variável sociodemográfica, e não como uma categoria teórica e explicativa (Escosteguy, 2002). Diferentemente, a pesquisa de recepção que revela um debate de gênero objetiva entender o sentido da mídia na vida feminina, a razão das mulheres buscarem os meios de comunicação e que implicâncias essa relação acarreta. 
66 Estudar a recepção a partir de uma perspectiva de gênero implica conhecer como e por que a mulher se aproxima de diferentes meios de comunicação, em que contexto recebe suas mensagens e que uso faz delas em sua vida. Isto permite acentuar a interação dos meios com a realidade social e cultural das receptoras, conhecer seus gestos e preferências, assim como as razões que fazem com que elas se apropriem dos meios (Charles, 1996, p. 43).

Por sua vez, uma noção que acompanha os Estudos Culturais desde suas origens é a valorização da classe social como um elemento definitivo na experiência cultural, coerente com a influência marxista da corrente. Há, no entanto, uma preocupação em não fazer uso do conceito de classe de forma reducionista. Escosteguy (2001, p. 60), afirma que é fundamental "compreender a cultura na sua 'autonomia relativa', isto é, ela não é dependente, nem reflexo, das relações econômicas, mas tem influência e sofre consequências das relações político-econômicas".

Certamente, a relativização da centralidade da classe social nos estudos de cultura é fundamental na busca por uma compreensão mais complexa. No entanto, essa preocupação tem sido extremada, fazendo com que, cada vez mais, a classe social - algumas vezes até mesmo considerada um "conceito ultrapassado" - passe a ser tratada apenas como um dado sociodemográfico ou mesmo seja esquecida. Fonseca (2006), percebe essa recusa também na Antropologia, o que vai de encontro com a importância da classe para as relações sociais. É possível inferir desse silenciamento que talvez não seja politicamente correto falar em classe social, ou em pobres, pois, dessa forma, se ressalta algo que se quer acobertar, a desigualdade social.

Ronsini (2007, p. 48) justifica o emprego do conceito de classe social afirmando que, no plano empírico, a classe permanece um princípio organizador da sociedade capitalista, da mesma forma que pauta diferenças profissionais, de renda, de educação, de acesso a bens culturais e a centros de poder. A autora afirma ainda que o uso do conceito parece ser mais adequado em uma sociedade desigual e excludente como a brasileira. Ronsini, contudo, distingue o modo como insere a classe social em suas observações do sentido tradicional marxista: "As análises hodiernas não se encaixam na teoria das classes como uma teoria da luta entre duas classes antagônicas pelo monopólio dos meios de produção" (Ronsini, 2007, p. 48), pois admitem que os conflitos não são pelo controle desses, mas pela inclusão dos sujeitos no capitalismo.

Para Martín-Barbero (2002, p. 14), apesar de desempenharmos múltiplos papéis em nosso diaa-dia, todos eles estão atravessadas pela classe social a que pertencemos, constituinte fundamental 
de nossas identidades. $\mathrm{O}$ autor tece uma crítica ao nivelamento entre a classe social e outras mediações:

66 a 'marca' singular e hegemônica dos atuais estudos de recepção diz respeito ao 'esquecimento da classe social' produzido pelo nivelamento de todas as categorias: etnia, gênero, idade, estrato social. É o processo mesmo de recepção que resulta desestruturado, sem fundamentação no 'processo social de construção de sentido'. A diferença de classe, ainda que mediada pela multiplicidade de distinções introduzidas pela etnia, gênero, idade, entre outras, não é uma diferença a mais, mas, sim, aquela que articula as demais a partir de seu interior e expressa-se por meio do habitus, capaz de entrelaçar os modos de possuir, de estar junto e os estilos de vida (Martín-Barbero (2002, p. 14).

\section{Jovens mulheres da periferia: quem são e como vivem}

A preocupação em investigar os papéis da família, da escola, da classe social e da telenovela na conformação da identidade feminina deve-se ao entendimento de que essas são referentes que afetam profundamente a socialização e a formação dos sujeitos em estudo. Entendemos que pesquisar a recepção através das mediações ${ }^{1}$ configura-se como uma forma válida de destacar essa autonomia relativa do receptor, compreendendo quais as fontes que atuam nas leituras da mídia.

Para termos tal compreensão, empreendemos uma etnografia da audiência, a qual se constitui do conhecimento originado da descrição do contexto de apropriação da mídia e refere-se a descrever os meandros do consumo midiático. Dessa forma, realiza-se uma análise atenta ao cotidiano, no que se refere ao bairro, à casa, às práticas, buscando observar a produção de sentidos a partir do receptor (Ronsini, 2007). Os instrumentos de coleta de dados utilizados foram entrevista em profundidade, formulário sociocultural, observação do espaço doméstico e assistência conjunta da telenovela. A etapa empírica da pesquisa estendeu-se de novembro de 2008 a dezembro de 2009.

O grupo pesquisado está composto por 12 jovens mulheres, de classe popular ${ }^{2}$, com idade entre 16 e 24 anos $^{3}$. As rendas familiares variam de $R \$ 500,00$ a $R \$ 1.600,00$. As condições econômicas do grupo se refletem em casas simples e pequenas, em que moram de duas a nove pessoas; na falta de carro entre as famílias ou na posse de carros de modelos antigos; no baixo grau de escolaridade - geralmente ensino fundamental incompleto - de pais, irmãos e das próprias 
garotas ${ }^{4}$. No momento da pesquisa de campo, três entrevistadas realizavam trabalho remunerado (babá, empregada doméstica e monitora de escola) e as demais eram exclusivamente estudantes e/ ou donas de casa.

Os recursos financeiros limitados têm papel central na configuração das identidades. Destacamos que os modos de ser mulher estão atravessados de forma pungente pela classe social. É por pertencerem à classe popular que as jovens aprendem que:

- a mulher tem que cuidar da casa, já que não poderão ter empregada doméstica, e, por isso, desde cedo aprendem a cozinhar, lavar roupa e limpar a casa;

- o trabalho feminino dificilmente significará um reconhecimento social, pois não possuem uma carreira ou uma profissão, e, sim, um trabalho, muitas vezes temporário e malremunerado;

- as chances de não terem os pais presentes (física e/ou afetivamente) aumentam, como é o caso da metade das entrevistadas;

- a televisão é a principal forma de lazer, dedicando-se, diariamente, muitas horas a seu consumo, em contraste a outras programações, como cinema e viagens, raridades entre as entrevistadas;

- a chance de pararem de estudar antes de completarem o ensino médio é grande, seja pela maternidade, pela necessidade de trabalhar - em casa, cuidando dos mais velhos e das crianças, ou fora, para contribuir com a renda doméstica -, pela discriminação escolar, pelo ensino básico deficiente - que poderá dificultar o acompanhamento da turma em uma escola de ensino médio do centro da cidade -, ou pela falta de exemplos de dedicação ao estudo;

- a gravidez na adolescência é mais comum do que em classes abastadas, e acarreta transformações drásticas.

As cinco entrevistadas que têm filhos afirmam que as gravidezes não foram planejadas, ou seja, tornaram-se mães por "circunstância", não para a realização do sonho de ser mãe. Todavia, sendo coerentes com o julgamento que fazem de que a maternidade deve ser prioridade na vida de uma mulher, tiveram suas vidas transformadas após o nascimento dos filhos e dedicam-se à criação deles. Entre as que são mães, é comum que seu sonho de vida seja proporcionar ao filho um futuro melhor, com uma situação financeira confortável e uma trajetória sem sofrimentos. 
A maternidade é considerada o aspecto mais importante na vida de uma mulher, sendo incompreensível para as entrevistadas a opção daquelas que não querem ser mãe. Ademais, o amor maternal é visto como algo "natural".

66 Ali por uns 25, 20 anos eu queria ter um [filho]. Ah, é bonitinho. (Bruna ${ }^{5}$ )

66 É uma companhia pra mim, porque, por mais que tu seja casada, tu tem a companhia do teu marido, mas tu sabe que um dia vocês vão se separá e pelo menos tu qué tê uma companhia pra ti não ficá sozinha. (Camila)

66 Eu não creio que uma mulher, assim, normal, não vá querê tê um filho. Um filho é uma benção na tua vida. (Emanuele)

66 Acho que toda mulher sonha em sê mãe, né? (Letícia)

66 Eu acho que todas têm que tê filho. Depois tá velho não tem ninguém, quem é que vai te cuidá? (Lucielen)

66 Eu, desde os 15 anos, eu quero tê um filho. Acho que não tem coisa melhor que sê mãe. [...] É uma experiência que eu quero tê, eu não seria mulher se eu não tivesse essa experiência, eu quero tê muito. (Rafaela)

66 Tu vai vê a criança na tua frente, tu vai ter o amor de mãe, né? Mesmo tu não querendo, tu vai ter o amor de mãe. Quando a mãe se torna mãe, automaticamente tu vai criar esse amor dentro de ti. (Raquel)

Natiele é a única entrevistada que não demonstra o grande desejo de casar e ser mãe.

66 Por mim, eu não quero sê mãe, brinco com o filho dos outros, mas meu eu não quero, muito obrigado. Criança, olha, incomoda muito. Ainda mais do jeito que tá, hoje em dia, essas criança que a gente ensina prum lado, elas caem pro outro, querem sempre o lado torto. Aí é melhor nem tê, se é pra tá se incomodando. (Natiele)

O trabalho, por seu turno, é elemento importante para a realização pessoal das garotas, porém, não almejam a independência financeira. Pensam a profissão como um modo de estar fora de casa, convivendo com outras pessoas que não as de suas famílias, e o salário como forma 
de terem um dinheiro próprio para fazerem suas compras pessoais, sem necessitar pedi-lo ao marido. Esse pensamento refere-se ao contexto social em que estão inseridas, no qual o homem é o provedor e a mulher apenas contribui para a renda familiar. Quando a mulher é a responsável pelo sustento da casa, geralmente é devido à "falta de um homem", o que não é o desejo delas. Preferem estar casadas e ter a proteção masculina. Silva, Torres e Berg (2009) falam da busca das jovens de classes populares por um "príncipe encantado", ou seja, pelo amor romântico de um homem, no qual depositam suas esperanças de um futuro melhor.

O comportamento para conseguir, e manter, a atenção e a afetividade desses homens "salavadores" é, com frequência, um ensinamento transmitido pelas famílias. Desempenhar bem as funções de esposa dedicada - e fornecedora de prazer -, dona de casa caprichosa e boa mãe é o que os pais (pai e mãe) mais valorizam na educação das filhas. Nas rotinas domésticas, as jovens, assim como seus companheiros, cresceram com os exemplos de pais que pouco ou nada contribuem nas tarefas domésticas, mesmo nas famílias em que as mães trabalham fora. Por isso, é comum a reprodução de uma dinâmica familiar em que a mulher realiza jornada dupla ou tripla - como no caso da entrevistada Paola, que possui trabalho remunerado, estuda e cuida da casa, sem a ajuda do marido.

\section{A codificação das representações femininas na telenovela}

Tomamos como objeto de análise a telenovela Caminho das Índias ${ }^{6}$, transmitida no horário das $21 \mathrm{~h}$ (novela das oito) pela Rede Globo. O estudo foi realizado a partir de: a) análise de seis capítulos 01 (primeiro), 10, 50, 90, 150 e 203 (último) -, que permitiram observar e exemplificar codificações hegemônicas, negociadas e opositivas; b) acompanhamento diário da telenovela, levando-se em conta a trajetória dos personagens, suas relações sociais e afetivas.

A importância de estudar as representações femininas apresentadas na telenovela, para posteriormente compreender sua recepção, é defendida por Hall. Buscando destacar tal reflexão, Morley (2006, p. 11-12) expõe que "certamente, poucos parecem ter notado a posição de Hall [...], ele insiste que a 'leitura preferencial' é, sem dúvida, uma propriedade do texto - a qual pode (e deve) ser identificada por uma análise cuidadosa do próprio texto."

A análise de representações femininas na novela Caminho das Índias tem a função de mostrar de que forma os estereótipos estão presentes no discurso midiático, que se soma aos discursos de outras instituições socializadoras - ou outras mediações - para oferecer estruturas de sentido 
para a construção da identidade feminina. Esses discursos são impostos de forma invisível e não se apresentam como imposições, mas como algo agradável, que serve a alguns interesses femininos, conquistando, assim, a cumplicidade das mulheres para sua própria subordinação (Charles, 1996; Bourdieu, 2007).

Uma das principais representações femininas na telenovela refere-se à valorização da maternidade, tal como Badinter (1985) se refere ao falar do mito do amor materno ${ }^{7}$. A obrigação de ser uma boa mãe, e mesmo de ser mãe, é constante em Caminho das Índias. Um exemplo disso pode ser notado com a personagem Ruth (Cissa Guimarães), que, apesar de retratar uma mulher independente, solteira e satisfeita com sua vida, foi tomada pelo desejo de tornar-se mãe. Não ser casada e mesmo não estar em uma idade ideal para engravidar não foram impeditivos, e a personagem optou pela "produção independente".

Por sua vez, a importância de ser uma boa mãe foi retratada, principalmente, por Melissa (Christiane Torloni) e Maya (Juliana Paes), sendo que a primeira fugiu aos padrões, e, a segunda, foi um "exemplo de mãe". Melissa, uma mulher fútil e obsessiva por beleza, tinha um "instinto materno" pouco desenvolvido, visto que se colocava à frente dos filhos, e envergonhava-se deles - da filha, por seu estilo de vestir e falar diferentes, e do filho, pela doença psiquiátrica (esquizofrenia). A personagem redime-se no final da novela ao comparecer à apresentação do filho na clínica psiquiátrica, mostrando aceitar sua doença.

Maya, apesar de ter se casado com Raj (Rodrigo Lombardi) estando grávida de Bahuan (Márcio Garcia), e não ter contado isso ao marido, foi apresentada como um modelo de mulher. Como mãe e esposa, Maya mostrou significativas virtudes, pois era dedicada à família e estava sempre bela. Ao casar-se, deixou o emprego para cuidar da casa, do filho e do marido. Enquanto isso, Raj permaneceu dedicado ao seu trabalho, mantendo o mesmo comportamento profissional após o casamento.

Renunciar à sua individualidade em nome da família não é uma atitude exclusiva da mulher oriental, como mostra a observação da personagem Sílvia (Débora Bloch). Após casar-se com Raul (Alexandre Borges), deixou de lado a docência e passou a ser esposa e mãe em tempo integral. $\mathrm{O}$ fim de seu casamento e a decadência financeira fizeram com que ela voltasse a trabalhar, mostrando-se uma mulher batalhadora. O prêmio de Sílvia, contudo, não foi encontrado na profissão, mas sim em um novo amor. O casamento com Murilo (Caco Ciocler) significou o recomeço e a felicidade para a personagem. 
Para a maior parte das personagens de Caminho das Índias, o trabalho era secundário ou mesmo inexistente, o que significaria, seguindo a reflexão de Mattos (2006) ${ }^{8}$, que as mulheres da novela, com algumas exceções, não podem ser consideradas modernas. A distinção mais marcante entre funções femininas e masculinas refere-se aos cuidados da casa, de um lado, e o trabalho no meio público, de outro (em funções como comerciante e médico), havendo nítida diferença de reconhecimento social e salarial entre os dois pólos. Outra separação comum está relacionada à hierarquia (Bourdieu, 2007), visto que, de um lado, estão chefes, como os executivos e empresários, e, de outro, as secretárias e empregadas domésticas.

Por outro lado, as personagens Inês (Maria Maya) e Leinha (Júlia Almeida) ofereceram dois importantes exemplos de representações em que a carreira profissional é aspecto importante para a realização feminina, e que desvincularam as mulheres da necessidade de estarem acompanhadas de um homem para alcançar a felicidade. Na trama, as jovens estiveram sempre solteiras e felizes, e seus prêmios finais vieram através de conquistas profissionais. Inês foi anunciada como a futura presidente da empresa da família Cadore, e Leinha recebeu proposta para trabalhar como produtora em Hollywood, tendo sua dedicação aos trabalhos audiovisuais reconhecida.

Assim, percebe-se que, na telenovela analisada, a relação entre mulher e trabalho foi apresentada de forma positiva: voltar a trabalhar foi o início da "volta por cima" de Sílvia; o emprego de Maya, em um call center, mostrou que a jovem tinha costumes mais modernos que as demais mulheres indianas; os trabalhos de Aída (Totia Meirelles) e Ciça (Aninha Lima) na clínica psiquiátrica compunham o retrato de duas mulheres "bem resolvidas"; Ruth era uma diretora dedicada que buscava melhorar a escola onde trabalhava; e a falta de uma ocupação produtiva por Melissa colaborou em seu retrato como uma mulher fútil. Contudo, o trabalho não era central para nenhuma das personagens principais da trama, e era a dedicação à família que distinguia as "boas mulheres". Portanto, em Caminho das Índias, permaneceu a representação do feminino vinculado ao espaço privado e do masculino, ao público.

\section{Leituras da telenovela: construindo os sentidos do feminino}

A televisão é o principal meio de comunicação consumido pelas jovens. La Pastina (2006, p. 35) observa que, para muitos telespectadores, a TV "é a principal, se não a única, fonte de informação". Entre as entrevistadas, a reflexão do autor se confirma. Elas leem pouco jornal, não consomem revistas ou livros, acessam pouco à internet e, quando o fazem, as páginas mais 
acessadas são as redes de relacionamento. O rádio, embora concorra com a televisão em tempo de consumo, serve somente para ouvir música, e não se configura num momento de integração familiar, como a TV e, especialmente, a telenovela.

As telenovelas, embora não durem mais que nove meses, reproduzem um mesmo modelo, que pouco muda de uma década para outra, há 50 anos. Assim, muitas jovens de 20 anos, como as entrevistadas, acompanham telenovelas desde a infância e, apesar de realizarem uma negociação na decodificação desses produtos, são educadas por eles, assim como pela escola, pela família e por outras instituições socializadoras. De tal forma, o gênero melodramático, ao apresentar basicamente as mesmas representações femininas ao longo de anos, constitui importante formador de modelos femininos.

A identificação com as personagens das novelas, mesmo que parcial, existe. A personalidade "guerreira" e humilde é o que há em comum entre as mulheres da ficção e as entrevistadas. A personagem Maria do Carmo (Susana Vieira), de Senhora do Destino (Rede Globo, 2004), seria a principal representante da mulher brasileira - grupo no qual as jovens se incluem - por sua "alegria", "autoestima" e "jeito guerreiro".

66 Pra mim ela é a típica mulher brasileira, né? De onde ela veio, conseguiu crescê na vida, mas não exageradamente, conseguiu o básico pra consegui vivê, né? Que as mulheres elas são guerreira, elas gostam de trabalhá, vão atrás daquilo que querem, conseguem aquilo, que querem, né? Não tem mais aquela história de que só o homem que pode, só o homem que faz. Não, agora é igual mulher e homem, né? O marido deixou ela, criou os filho sozinha, conseguiu educá os filho, estudaram, se formaram, ela conseguiu sê alguém na vida, conseguiu um nome reconhecido, né? (Raquel)

Uma análise específica da recepção de algumas personagens femininas de Caminho das Índias permite a explicitação mais detalhada das opiniões das informantes sobre a mulher na telenovela. Maya teve avaliação positiva de 11 entrevistadas, que admiram sua resistência ao sofrimento e seu amor pelo filho. Apenas uma jovem fez um julgamento negativo da personagem, descrevendo-a como "muito dramática, muito mocinha sofredora, não tem iniciativa". Nessa perspectiva, a personagem Maya iria contra o enfatizado valor do espírito "guerreiro", que as receptoras salientam nas personagens femininas.

Contrastando com Maya, Melissa, do núcleo ocidental, teve suas atitudes reprovadas pelas telespectadoras. Apenas duas jovens gostavam da personagem, pois a consideraram uma "mulher 
de atitude". Ambas se confessaram, em outras questões, vaidosas, e não se importaram com os cuidados permanentes de Melissa com a beleza. Outras três entrevistadas mostraram simpatia pela personagem - pois o modo caricato como suas extravagâncias eram apresentadas divertia as jovens -, porém, não deixaram de criticar suas atitudes com os filhos. Por outro lado, sete informantes destacaram a futilidade, o egoísmo e a insensibilidade da personagem com as necessidades do filho esquizofrênico (Tarso).

66 A Melissa é o tipo da mulher fútil, só pensa em beleza, em roupa, em joia, bem mulher fútil, bem sem noção, sem cultura, sem estrutura, sem inteligência, mulher bem que gosta de banalidade. Enquanto o filho dela tá com problema, ela tá pensando em botox, em cabelo, em roupa, joia, perfume, viagem, bem a madame mesmo. (Carol)

66 A Melissa era muito fútil, ela só pensava nela, não via o problema do filho dela, não via nada, ela só olhava pra si mesma, pra beleza dela, e não se preocupava com os outros que tava na volta dela. (Natiele)

66 Ela teria que se colocá mais no lugar de mãe, não querê que o filho fosse o bonito da capa da revista, o perfeito. (Paola)

66 Ela é muito louca (risos), muito louca, ei! Ela só qué creminho, ela não tem noção do que acontece com o filho dela, ela só qué sabê de gastá dinheiro, sabe? (Rafaela)

Desse modo, fica claro que, para as entrevistadas, é papel principal de uma mulher ser uma mãe dedicada e atenta aos filhos. Na ótica delas, o egoísmo é uma grande falha moral, incompatível com a maternidade.

O aspecto cômico da telenovela teve a personagem de Norminha (Dira Paes) como um de seus principais representantes. Metade das entrevistadas declarou gostar da personagem, pois se divertiam com sua atuação. Não deixaram, contudo, de criticá-la por ser infiel ao marido.

66 A Norminha, tá loco! Nem tem o que falá da Norminha. Norminha, tá loco! [...] Mais engraçada que todos da novela. (Lucielen)

66 A Norminha era legal (risos)... era legal. Eu gostava mais quando ela dava o leitinho pro Abelzinho (risos). Era legal, só que, por um lado, ela era errada, porque ela era casada, não devia fazê o que ela fazia, mas era divertido o papel dela. (Natiele) 
66 Cinco informantes desaprovaram completamente a personagem, pois era 'sem vergonha', 'falsa', 'barraqueira' e 'vileira'.

66 A Norminha é aquela mulher escandalosa, barraqueira, bem da vida mesmo, que traiu o marido, não tem educação, assim, não é uma mulher de fraquejo, é bem aquela mulher vileira mesmo, de vida, eu acho pelo menos. Ela é uma mulher leviana, que não mede as consequências das coisas que faz. (Carol)

Expressando um ponto de vista menos comum, Camila afirmou que Norminha representava grande parte das mulheres brasileiras e era uma personagem positiva para as mulheres, pois "tá mostrando o que a mulher pode fazê, né?".

Suellen (Juliana Alves) não teve nenhuma avaliação negativa, sendo destacada como uma mulher liberal, alegre, espontânea e determinada. A decisão por continuar trabalhando como balconista, mesmo após se casar com um médico que poderia sustentá-la, foi a atitude de Suellen mais aplaudida pelas receptoras, sendo citada positivamente por todas, pois representou uma mulher independente e sem interesses financeiros no casamento. "Eu achei bem legal da parte dela continuá trabalhando, ela não se escorou no doutor" (Paola). A atitude destacada em Suellen pelas informantes alude ao que Mattos (2006) afirma sobre os relacionamentos amorosos de mulheres modernas, que veem o romance como um fim em si mesmo.

De forma mais geral, as entrevistadas identificaram a mulher de Caminho das Índias como prioritariamente dedicada a casa, filhos e marido. Essa imagem destacou-se no núcleo indiano, mas também foi comum entre as representações de mulheres brasileiras. Oito entrevistadas não diferenciaram a representação da mulher indiana a da brasileira, pois o cuidado da casa e o "ter atitude" foram aspectos em comum.

66 Acho que mais em casa, porque muito pouco se trabalha ali, mas é em casa, no serviço de casa que eles mostram mais. Na Índia é tudo bem dizê da casa, não trabalham fora. E no Brasil, a Sílvia não trabalha, a Yvone não trabalha, a Melissa não trabalha, aquilo é só comprando, né? Então eu acho que é mais dona de casa. (Camila)

66 As mulheres, elas tinham atitude, né? Com atitude, elas iam em frente naquilo que elas queriam, a Melissa era uma delas, né? Elas iam em frente, a Maya também. (Emanuele) 
As outras quatro informantes distinguiram os modos de ser da mulher que vive no Brasil da que vive na Índia. Enquanto as brasileiras são independentes, as indianas são submissas e vivem apenas para fazer as vontades do marido e da família dele.

66 Era mostrada na parte da Índia como a mãe, a dona de casa, deveria ficá só em volta dos filhos, do marido, eu acho que ali era mais a empregada da casa. Tinha tudo, tinha joia, mas ela teria que fazê tudo, ela não poderia trabalhá, não poderia estudá, não poderia fazê nada, só vivê em volta dos filhos e do marido. Já aqui, na parte do Brasil, tinha a parte legal da Duda, que ficô cuidando do filho sozinha, da mãe da Camila, que tomava conta das duas filha, trabalhava bastante, bem legal, mostrá pra mulher que ela pode tomá conta duma casa, tomá conta das filha sem dependê de ninguém. Achei bem legal. (Paola)

Por fim, a novela ensinaria às mulheres, na perspectiva das jovens, valores modernos, relacionados à sua liberdade pessoal: "Mostra que mulher trabalha, tem sua casa, tem sua vida, não precisa dependê só do homem" (Natiele). Os principais ensinamentos podem ser assim sintetizados: ser independente, característica que está relacionada à vida profissional; ter atitude, que diz respeito a não serem submissas; e ser guerreira, que se refere a lutar por seus objetivos, pessoais e profissionais.

Por outro lado, para três entrevistadas, a telenovela também ensinaria as mulheres a "se preservarem", mostrando a necessária dignidade moral feminina, e ofereceria exemplos de mulheres submissas, que têm como objetivo de vida casar e agradar o marido. "Na novela, mostra que a mulher tem que tá agradando o homem, mas, na minha opinião, acho que os dois tem que sê tratado igual." (Rafela). Há ainda a avaliação de Paola, que considera que a novela não ensina nada às telespectadoras.

\section{Considerações finais}

Estudar a identidade feminina é, primeiramente, buscar entender o que torna as mulheres seres específicos. Seu sexo importa, especialmente por legitimar as diferenças entre homens e mulheres, com as quais ambos convivem durante a vida. Porém, é na cultura do cotidiano - da classe social, da família, da escola, da mídia, da igreja, do bairro - que as identidades são conformadas, negociadas, reajustadas. Importante atentar, no entanto, que, mesmo enquanto mulheres, não constituem um grupo homogêneo, isto é, não basta nascer mulher para constituir a identidade feminina. 
A telenovela, produto ímpar para pensar as representações femininas, apresenta algumas aberturas ideológicas no tocante às relações pessoais e oportuniza a discussão de assuntos considerados tabus, como o sexo. Do mesmo modo, apesar de não ser esta representação hegemônica, apresenta mulheres autônomas, que alcançam a independência pessoal através do trabalho. Ao mesmo tempo, a telenovela (re)produz um modelo feminino tradicional, que vincula a mulher ao papel de mãe, prioritariamente, esposa e dona de casa, deixando a esfera pública como campo de atuação majoritariamente masculino. Assim, entendemos que há uma abertura nas representações das mulheres, no entanto, não se percebe uma abordagem propriamente igualitária dos gêneros.

Através dos apontamentos acerca da recepção da telenovela, percebemos que as leituras das jovens reproduzem o que é apresentado no programa, oscilando entre essas duas formas de representar as relações de gênero. Segundo as entrevistadas, o programa exibe uma mulher moderna, que "não precisa depender do homem", mostrando a mulher que trabalha e é a "senhora do seu destino" ${ }^{\prime \prime}$. Por outro lado, não deixam de relacionar a mulher ao papel prioritário de mãe, bem como de esposa, expostos na telenovela e valorizados na educação familiar. Acostumadas com exemplos de submissão feminina na família e no bairro - que elas mesmas relatam -, as entrevistadas leem as representações oferecidas pela telenovela como uma valorização da mulher. Assim, entre as mediações empíricas estudadas - família, classe social e telenovela -, é a ficção seriada a que propõe um discurso feminino mais inovador. Esse discurso, mesmo que pouco se concretize em prática, é fundamental, pois também constitui a identidade feminina.

Acreditamos, como Charles (1996), que, apesar de obras ficcionais, é papel da telenovela ampliar o leque de representações femininas, fugindo das imagens simplificadas que reduzem a mulher à vida privada - ainda hegemônicas -, e venham a favorecer uma relação mais igualitária entre os gêneros. "A projeção de novas identidades femininas nos meios é uma exigência da modernidade e um aspecto nodal da comunicação para o desenvolvimento" (Charles, 1996, p. 49).

\section{NOTAS}

1 O conceito de mediações é tão complexo que Martín-Barbero não oferece uma definição clara, nem situa as origens do mesmo. Essa categoria, segundo Signates (2006), é citada 37 vezes em "De los medios a las mediaciones" 
(Martín-Barbero, 1987), em cinco sentidos diferentes: a) como construto ou categoria teórica; b) como discursividade específica; c) como estruturas, formas e práticas vinculatórias; d) como instituição ou local geográfico; e) como dispositivo de viabilização e legitimação da hegemonia. Para Orozco (2001, p. 23), mediação pode ser entendida "como um processo estruturante que configura e orienta a interação das audiências e cujo resultado é o outorgamento de sentido por parte dessas aos referentes midiáticos com os que interatuam".

2 A classificação social das entrevistadas foi definida mediante a metodologia da estratificação sócio-ocupacional, na qual a família é classificada a partir do membro melhor situado economicamente. Os grupos resultantes são reunidos em quatro camadas: alta (proprietários e alta classe média); média (média classe média e proprietários de pequeno negócio urbano); média baixa (baixa classe média, operários e trabalhadores autônomos); baixa (camada inferior de operários, assalariados populares e trabalhadores autônomos, empregados domésticos e não ocupados) (Quadros; Antunes, 2001). Essa divisão serviu como ponto metodológico de partida para a busca de entrevistadas que fizessem parte do estrato social pretendido por esta pesquisa (classes baixa e média baixa). No entanto, nossa compreensão de classes/grupos populares vai além do que se define pelas profissões, ou pela posse de bens materiais. Além da importância da ocupação e da renda familiar, consideramos que as classes populares possuem uma cultura específica, um habitus de classe, no sentido bourdiano, que conforma os modos de agir e pensar.

3 A delimitação etária segue a divisão do IBGE, que define entre 15 e 24 anos a faixa em que estão inseridos os jovens no Brasil.

4 Toma-se a reflexão de Mattos (2006, p. 182) como referência para destacarmos a importância da presença dos pais no ambiente doméstico para a conformação identitária, e a ausência mais comum dos pais na classe popular. A autora afirma: "Ainda que a classe média esteja convivendo com mudanças na estrutura familiar, o que vem ocorrendo é a formação de novas configurações de família, e não a desagregação familiar, muito mais frequente na classe baixa. Mesmo que os pais de classe média não vivam juntos, isso não implica a perda de suporte e da referência de ambos os pais para os filhos".

5 Todos os nomes usados para as entrevistadas são fictícios.

6 Caminho das Índias estreou dia 19 de janeiro de 2009 e, após 203 capítulos e oito meses no ar, terminou em 12 de setembro de 2009. A trama foi escrita por Glória Perez e dirigida por Marcos Schechtman.

7 Em "Um amor conquistado. O mito do amor materno", Badinter (1985) demonstra, por meio de inúmeros indícios - como os exemplos das mães frias que tendiam a abandonar os filhos, na França urbana dos séculos XVII e XVIII - que o amor materno inato é um mito. Esse cuidado é, na realidade, uma construção social. Porém, faz parte do imaginário da mulher do nosso século acreditar que tal amor nasce conosco e que, portanto, possuímos um "instinto materno".

8 Para Mattos (2006, p. 172), a mulher moderna se caracteriza "por construir sua identidade a partir do trabalho e compreender as relações entre ela e os homens como um fim em si mesmo. [...] $\mathrm{O}$ trabalho, tanto na sua dimensão econômica quanto na sua dimensão existencial, seria para a mulher moderna sua principal fonte de reconhecimento social."

9 Fazendo referência à personagem considerada o retrato da mulher brasileiro, Maria do Carmo, da novela Senhora do Destino. 


\section{REFERÊNCIAS}

BADINTER, Elizabeth. Um amor conquistado: O mito do amor materno. Rio de Janeiro: Nova Fronteira, 1985.

BOURDIEU, Pierre. A dominação masculina. Rio de Janeiro: Bertrand Brasil, 2007.

CHARLES, Mercedes. Espejo de Venus: una mirada a la investigación sobre mujeres y medios de comunicación. Signo y Pensamiento, n. 28, 1996.

ESCOSTEGUY, Ana Carolina. A contribuição do olhar feminista. Revista InTexto, Porto Alegre, n. 3, 1998.

Cartografias dos estudos culturais: uma versão latino-americana. Belo Horizonte: Autêntica, 2001.

. Os estudos de recepção e as relações de gênero: algumas anotações provisórias. In: Ciberlegenda, Disponível em <http://www.uff.br/mestcii >, n. 7, 2002.

. (Org.). Comunicação e gênero: a aventura da pesquisa [recurso eletrônico]. Disponível em: <http://www.pucrs. br/edipucrs/comunicacaoegenero.pdf $>$. Porto Alegre: EDIPUCRS, 2008.

FONSECA, Claudia. Classe e a recusa etnográfica. In: BRITES, Jurema; FONSECA, Claudia (Orgs.). Etnografias da participação. Santa Cruz: EDUNISC, 2006.

JACKS, N. A.; MENEZES, Daiane; PIEDRAS, Elisa. Meios e Audiências. A emergência dos estudos de recepção no Brasil. Porto Alegre: Sulina, 2008.

LA PASTINA, Antonio C. Etnografia de audiência. Uma estratégia de envolvimento. In: JACKS, Nilda; PIEDRAS, Elisa (Org.). O que sabemos sobre as audiências?: estudos latino-americanos. Porto Alegre: Armazém Digital, 2006.

MARTIN-BARBERO, Jesús. De los medios a las mediaciones: comunicación, cultura y hegemonía. Barcelona: Gustavo Gili, 1987.

. Prefácio. In: LOPES, Maria Immacolata Vassalo de; BORELLI, Silvia Helena Simões; RESENDE, Vera da Rocha. Vivendo com a telenovela: mediações, recepção, teleficcionalidade. São Paulo: Summus, 2002.

MATTOS, Patrícia. A mulher moderna numa sociedade desigual. In: SOUZA, Jessé (Org.). A invisibilidade da desigualdade brasileira. Belo Horizonte: Editora UFMG, 2006.

MEIRELLES, Clara Fernandes. Prazer e resistência: A legitimação do melodrama nos contextos acadêmicos. Dissertação (Mestrado em Comunicação e Cultura) - Universidade Federal do Rio de Janeiro, Rio de Janeiro, 2009.

MORLEY, David. Unanswered questions in audience research. Revista e-Compós, n. 6, 2006.

OROZCO, Guillermo. Televisión, audiencias y educación. Buenos Aires: Norma, 2001.

QUADROS, Waldir J. de; ANTUNES, Davi J. N. Classes sociais e distribuição de renda no Brasil dos anos noventa. Cadernos do CESIT, n. 30, 2001.

RONSINI, Veneza Mayora. Mercadores de sentido: consumo de mídia e identidades juvenis. Porto Alegre: Sulina, 2007. SIGNATES, Luiz. Estudo sobre o conceito de mediação e sua validade como categoria de análise para os estudos de comunicação. In: SOUSA, Marcos Wilton de. Recepção mediática e espaço público. Novos Olhares. São Paulo: Paulinas, 2006. SILVA, Emanuelle; TORRES, Roberto; BERG, Tábata. A miséria do amor dos pobres. In: SOUZA, Jessé. Ralé Brasileira. Quem é e como vive. Belo Horizonte: Editora UFMG, 2009. 